PART III

MARKET PERFORMANCE: QUANTITATIVE TESTS 
CHAPTER EIGHT

\section{MARKET INTEGRATION}

\subsection{Introduction}

In December 1438, after more than a year of grain shortages, the Council of Holland renewed the trade restrictions that had been introduced in the year before; they included export prohibitions for grain and beer and a strict supervision of the internal grain trade. The words that were used on this occasion betray despair: the Council 'could not think of anything better to provide our poor community with grain.' ${ }^{1}$ Apparently, Holland grain markets were unable to cope with circumstances of extreme scarcity. This is perhaps not surprising: between 1437 and 1439 dearth was causing serious problems in much of northwestern Europe. It is hardly realistic to expect that Holland commodity markets would have been efficient enough to allow the county to escape these problems altogether. The question is: did Holland markets do a better job than markets elsewhere-not just during this crisis, but also in normal years?

The preceding chapters have shown that, in late medieval Holland, a framework of commodity market institutions developed that might be expected to have lowered transaction costs and facilitated exchange. It now remains to be seen if these expectations came true; in other words, whether quantitative measurements support the hypothesis that commodity markets in Holland performed well when compared with markets elsewhere. This subject is addressed in this and in the following chapter. The present chapter focuses on market integration. The underlying assumption, derived from New Institutional Economics, is that favourable institutions, by reducing transaction costs, promote the rise of well-integrated markets. Chapter 9 will examine market orientation. Starting from the view that efficient market institutions and low transaction costs encourage and facilitate participation in market

${ }^{1}$ Unger, 'Hollandsche graanhandel', 492-493 (‘... niet beters en connen gevinden om onse arme gemeynte gesustineert te worden van koorne.'). 
transactions, an attempt is made to estimate the degree of commercialisation of late medieval society in Holland.

Market integration and market orientation have been selected because they can be seen as general indicators of market performance. In this way, they provide a valuable addition to the earlier chapters, which each focused on only a part of the institutional framework. Market integration and market orientation have the advantage of reflecting the impact of the institutional framework as a whole for the economy at large. However, precisely because of the general nature of the two indicators, they cannot be expected to provide absolute proof of a causal relation between certain institutions on the one hand and market performance on the other. Therefore, the quantitative approach in this and the following chapter should be seen as complementary to the qualitative but much more detailed information presented earlier. Only by combining the results of both is a fair assessment of the relation between institutions and market performance possible.

The nature of the relation between institutions, market integration, and economic growth is controversial. Some of the discussions on this issue are linked to the debate on the Great Divergence. They evolve around the question of whether greater market efficiency, supported by more favourable institutions, was one of the elements that gave premodern Europe an advance over the rest of world. Carol Shiue and Wolfgang Keller, for instance, who are critical of this assumption, argue that on the eve of the Industrial Revolution grain markets in China's Yangtze delta were just as integrated as grain markets on the European continent. They stress that market integration in Europe improved suddenly and dramatically only in the early 19th century and conclude that market integration was a reflection of accelerated economic growth rather than a pre-condition for it. The opposing view is reflected in a recent analysis of 18 th-century Indian grain markets by Roman Studer, who does not deny that market integration in Europe increased substantially in the 19th century, but demonstrates that in the late 18th century grain markets in Europe nevertheless showed much higher levels of integration than those in India. ${ }^{2}$

${ }^{2}$ Shiue and Keller, 'Markets in China and Europe'; Studer, 'India and the Great Divergence'. Studer believes the Yangtze delta studied by Shiue and Keller was an exception rather than the rule. 
If this is true, then the next question is when and how Europe had obtained this advance. Opinions differ on the development of European market integration during the early modern era and on the role of institutions in this process. One group of scholars sees signs of increasing integration, supported by institutional improvements. Karl Gunnar Persson, for instance, claims that the leap in the 19th century was preceded by a gradual process of increasing integration on a much lower level. He states that by the middle of the 18th century the contours of a European wheat market were beginning to show, and attributes this to the gradual emergence of robust trading and information networks. ${ }^{3}$ Similar conclusions have recently been drawn for the North Sea and Baltic region in particular. ${ }^{4}$ For rural England, it has been argued that regional specialisation, combined with interregional integration, made significant progress in the course of the 17 th century. ${ }^{5}$ Others, however, deny that the early modern era brought significant improvement. A recent contribution by Victoria Bateman claims that early modern market integration levels followed a U-shaped trend, dropping off in the late 16 th and 17 th centuries (mainly due to warfare) but recovering afterwards. As a result, market integration in 1800 was at about the same level as in $1500 .^{6}$

This shifts the rise of market integration back to the Middle Ages. Once again, opinions differ on scope, intensity, and progress. Johan Söderberg, for example, has demonstrated important similarities in grain price movements in the late 14 th and 15 th centuries within a cluster of cities and towns in northwestern Europe, both on the North Sea coasts and further inland-in the southern Low Countries, the north of France, the present-day Netherlands, and the south of England. ${ }^{7}$ Richard Unger, on the other hand, stresses that even at the end of the Middle Ages most grain consumed in the cities of northwestern Europe came from nearby, and only in years of dearth were large volumes of grain brought in from further afield. Unger concludes that interregional integration in the North Sea region was weak in the 14 th and 15th centuries and only gradually became stronger in the 16 th century, although he does admit that at least in the southern Low

\footnotetext{
3 Persson, Grain Markets, 91-113, esp. 100.

4 Jacks, 'Market Integration'; Van Bochove, Economic Consequences, 30-55.

5 Kussmaul, General View, esp. 111-113.

6 Bateman, 'Evolution of Markets'.

7 Söderberg, 'Prices in the Medieval Near East and Europe', 9-13.
} 
Countries a well-integrated regional market had already formed before that period. ${ }^{8}$ On this last issue, Unger follows the conclusions of Van der Wee in his study of the Antwerp market and Marie-Jeanne TitsDieuaide in her analysis of grain prices in Brabant, both of whom conclude that an integrated regional market was in existence in the 15th century. ${ }^{9}$

This strongly suggests that on a regional level a considerable degree of market integration had been reached by the end of the Middle Ages, but it is still unclear when this process began. For England, with its abundance of early price data, Gregory Clark claims that an efficient and coherent market for grains on a national level, with only limited price differentials between locations, had emerged as early as the beginning of the 13th century. ${ }^{10}$ Certainly, it has been argued that England was a special case. James Galloway, linking market integration to England's institutional framework, believes the emergence of strong central government at an early stage had helped reduce transaction costs through ensuring a stable currency, imposing national standards for weights and measures, removing internal fiscal or political barriers to trade, and providing legal means for contract enforcement. ${ }^{11}$ However, whether this really gave England an advance with regard to market integration is doubtful; since 13th-century price data for continental northwestern Europe are lacking, a comparison for this period cannot be made.

Therefore, this chapter focuses on the late 14 th and early 15 th century, when data become more abundant. It compares levels of market integration for Holland, England, and the southern Low Countries at that point in time, and attempts to relate the findings to some of the characteristics of the organisation of markets outlined in the previous chapters. The analysis focuses on wheat prices for two very practical reasons: firstly, the availability of more and earlier price data than for any other commodity (although in Holland they are by no means abundant); and secondly, the possibilities for interpretation and comparison

${ }^{8}$ Unger, 'Thresholds for Market Integration', esp. 350-352. Cf. Unger, 'Feeding Low Countries Towns', 336-338, where the author voices a more optimistic view on the degree of market integration.

9 Van der Wee, Growth of the Antwerp Market I, 23-24; Tits-Dieuaide, Formation des prix céréaliers, 36-44.

${ }_{10}$ Clark, 'Markets and Economic Growth', 8-13. Cf. Farmer, 'Prices and Wages', 742-744.

${ }^{11}$ Galloway, 'One Market or Many?', 23. 
offered by the literature-the integration of markets for wheat is a wellresearched subject. It is true that wheat markets may not be representative in every respect for grain markets in general or for commodity markets in a wider sense. Wheat was more expensive than rye, barley, and oats, and therefore better able to bear the costs of transport than the cheaper grains. More importantly, Holland was dependent on the import of bread grains, a fact that may have brought some specific elements to the grain trade. On the other hand, this also means that wheat market integration probably demonstrates the limits of the possibilities provided by the framework of market institutions and in this sense can be seen as an indicator of the efficiency of that framework.

The theory is simple. Institutional economists link market integration to institutional efficiency: institutions that provide security and facilitate the matching of supply and demand reduce transaction costs and thus promote the rise of integrated markets. However, in practice a given set of institutions may affect market integration in different and sometimes contradictory ways. Furthermore, non-institutional factors such as transport costs can also have a profound impact on market integration. This is why this chapter first outlines in what ways both institutional and non-institutional factors can be expected to have affected market integration in medieval Holland. Next, after an explanatory note on the methods and data that have been used, price volatility is discussed-the fluctuation of prices over time. Well-integrated markets are usually less volatile because highs and lows are more easily levelled out by grain transports from surplus to shortage regions: in this sense, volatility can be seen as the result of market integration. Following this, we will look at the underlying integration across distance-not primarily price convergence, as transport costs will always cause price differentials, but rather the co-movement of prices in different locations.

\subsection{The impact of institutional and NON-INSTITUTIONAL FACTORS}

The debate on the benefits of integrated markets goes back to the second half of the 18th century, when the French économistes attacked the traditional regulation of food provisioning practised by urban and central authorities. They claimed that export prohibitions, forestalling prohibitions, compulsory staples, checks on private grain stocks, 
public granaries, and bread price regulation ultimately did not have the desired effect of stabilising prices. These measures actually aggravated problems, in two ways: in the short run, they hampered the free flow of goods that could have evened out local shortages; and in the long run, they discouraged competition between producers and thus blocked investments in production. Regulation of the type criticised by the économistes was indeed common practice in Europe's pre-modern grain markets. The exact nature, scale, and intensity varied, but authorities everywhere tried to ensure the transparency of markets and ban collusion and speculation. It should be added, however, that rules were usually only rigidly enforced in periods of dearth; moreover, authorities only very rarely tried to directly control prices by setting a maximum. ${ }^{12}$

The effects of regulation on grain prices are not quite clear. According to Persson, there is no evidence that the économistes were correct in their claim that regulation made matters worse, whereas there are indications that strict regulation did contribute to the goal of softening extreme price fluctuations. ${ }^{13}$ The Ghent grain staple, for instance, is thought to have provided the urban population with a stable supply of cheap grain (even though Ghent's privileged position meant that other towns could not enjoy the same advantage, as we saw earlier). ${ }^{14}$ Yet Persson has also shown that in the early modern era the effects of regulation were limited: even in the most rigidly controlled markets, price volatility did not fall below a certain threshold level. ${ }^{15}$

Looking at the organisation of Holland's medieval grain markets from the perspective of this discussion, elements reflecting both sides of the argument can be discerned. The previous chapters have shown that Holland markets were relatively open and informal, which should have enhanced market integration. Urban markets were usually easily accessible: outside traders and merchants (people from out of town, non-burgesses or non-guild members) faced few restrictions. Coercion was uncommon: urban market districts remained flexible and there were few restrictions to informal trade in the countryside. In addition, the balance of powers provided checks on excessive taxation of trade

${ }_{12}$ Persson, Grain Markets, 1-10, 72-78; Gras, Evolution of the English Corn Market, 68-69.

${ }_{13}$ Persson, Grain Markets, 86-90.

${ }_{14}$ Boone, Gent en de Bourgondische hertogen, 21-23.

${ }_{15}$ Persson, Grain Markets, 106-113. 
by the count, lords, and towns: tolls and impositions were moderate. The absence of uniformity in weights and measures and the weakness of cross-boundary mechanisms for contract enforcement did work in the opposite direction, but as argued earlier the effects were probably mild.

On the other hand, the grain trade was in some respects an exception: practices and regulations did not differ as much from those in the neighbouring regions as they did for many other commodities. Firstly, urban authorities in Holland, as did their counterparts elsewhere in Europe, intervened in the grain trade in the interest of urban food provisioning. Bread was probably their first concern: bakers were subjected to a series of regulations on the weight and quality of bread, and bread price regulation is found in Holland towns from at least the early 15 th century onwards. ${ }^{16}$ But town governments also regulated the grain trade in their attempts to promote transparency and prevent speculation. ${ }^{17}$ The early 15 th-century Leiden by-laws provide an illustration: grain sales on Saturday, the day of the weekly market, were restricted to market hours and had to take place in public; during the rest of the week grain could be sold only for the price it had fetched on the previous Saturday. The resale of grain purchased at the market was prohibited, and exports of this grain were restricted. Forward transactions and the financial obligations ensuing from them had to be officially registered with the court of aldermen, and the term for such transactions was limited to six weeks at most. ${ }^{18}$ Secondly, as discussed in Chapter 3, some of the towns in Holland's few grain-producing regions possessed a regional grain trade monopoly, despite the absence of a tradition of coercion. Goedereede and Naarden enjoyed such a regional staple privilege even in the 14th century, and Brielle may have been in the same position.

However, strict enforcement of urban grain trade regulation was probably limited to times of dearth; in fact, some of the Leiden rules, such as the export restriction, may well have been intended as crisis interventions in the first place. Moreover, the Leiden regulations are modest in comparison to the very elaborate set of rules that structured

\footnotetext{
16 Unger, Levensmiddelenvoorziening, 105-109. The only late 14th-century case that Unger mentions comes from Dordrecht, which may very well, as so often, have been an exception.

17 Ibid., 56-61.

18 Hamaker, Middeleeuwsche keurboeken Leiden, 4, 234, 494-495.
} 
the retail grain trade in Ghent. ${ }^{19}$ Ghent, admittedly a very prominent case, expected all grain trade to take place at one of the officially designated market places, strictly prohibited all forestalling, and issued rules to protect consumers determining precisely when and where bakers, brewers, millers, and merchants could buy grain. In times of dearth, merchants were, moreover, obliged to sell part of their stocks daily, consumers could buy only limited amounts, and all exports were prohibited. ${ }^{20}$

Likewise, even though in Holland some regional grain trade monopolies existed, it was not a general pattern. As discussed in Chapter 3, Alkmaar-also a market centre for a grain-growing district-failed in its attempts to establish a monopoly for its weekly market. Delft forbade its own burgesses to buy grain in the direct vicinity of the town, but apparently did not try to impose a similar prohibition on others. ${ }^{21}$ As we shall see shortly, the Catharinagasthuis (St. Catherine's Hospital) and Leeuwenhorst Abbey, two religious institutions in the Leiden region, had no trouble buying grain directly from producers in the Delft region. Maintaining that there were no differences at all would therefore stretch the argument too far. Despite nuances, the hypothesis that the organisation of Holland grain markets facilitated market integration is still a valid point of departure.

Other factors besides the institutional framework may also have had an impact on the level of market integration in Holland. The most important of these factors is the exceptional position of Holland with regard to bread grain provisioning. Holland imported more grain, in relative and perhaps even in absolute terms, than any of its neighbours. In this respect, Holland was very unlike England, which at least until the early 14th century was quite able to sustain its own population. England imported grains on a significant scale only in years of dearth. For London, there is evidence of occasional grain shipments from Germany, Flanders, and even the Mediterranean. ${ }^{22}$ Exports were

${ }_{19}$ The retail trade served the local consumers; the grain staple regulated only the wholesale trade.

${ }^{20}$ Bigwood, 'Gand et la circulation', 439-443.

${ }^{21}$ Fruin, 'Oudste der tot dusver bekende keurboeken van Delft', 313 (probably early 15th century); Soutendam, 'Oudste keurboek van Delft', 518 (probably late 15th century).

${ }^{22}$ Campbell et al., Medieval Capital, 69. 
probably much more frequent, although they still involved only a tiny fraction of the country's cereal production. ${ }^{23}$

With the subsistence crises of the first half of the 14th century, England's grain exports declined significantly. Exports were tied to a system of royal licenses; the restrictions on trade embodied by this system were supported by the Commons, fearful of shortages. Only at the end of the century did the grain trade revive. The lifting of export restrictions in 1394 was probably both a reflection of and a stimulus for this revival: Englishmen no longer required a license to ship cereals overseas, as long as they paid the regular custom duties and did not take their cargo to an enemy nation. In 1437 a condition was added: the grain price had to be below a certain level for export to be permitted. From the port towns on the coasts of Norfolk and Suffolk, grain was transported to Flanders and Holland on a regular basis. Quantities were usually modest; but in times of dearth and high prices on the continent, England could be an important source of supply for the Low Countries. ${ }^{24}$

Unlike England, Flanders was unable to feed its growing population. This may have been the case even in the 12th century, but it became an increasingly pressing problem with the progress of urbanisation in the 13 th and 14 th centuries, a problem that could only be solved by large imports of bread grains. ${ }^{25}$ By far the most important external supplier was the north of France. Wheat from Hainault, Artois and the region around Lille, Douai and Cambrai was transported north over the rivers Scheldt and Lys to be consumed in the towns of Flanders and Brabant. ${ }^{26}$ At the same time, Flanders continued to produce grain on its own soil. For the Oudenaarde region, it has been estimated

\footnotetext{
${ }^{23}$ In the first decade of the 14th century, 13,000 quarters of grain were exported, whereas the production of the London region alone, according to the most probable estimates, was 800,000 to 1,100,000 quarters. (Export figures from Gras, Evolution of the English Corn Market, 111; production in London region calculated from Campbell et al., Medieval Capital, 35, 76 (London consumption of 165,000 quarter $=15$ to $20 \%$ of regional production)).

${ }_{24}$ Gras, Evolution of the English Corn Market, 111, 134-138; Kerling, Commercial Relations, 105-107; for imports of English grain in the southern Low Countries TitsDieuaide, Formation des prix céréaliers, 153-155. Cf. for the grain trade from England to Holland in the late 15th and early 16th century, Van Tielhof, Hollandse graanhandel, $40-49$.

${ }^{25}$ Nicholas, 'Of Poverty and Primacy', 31-32.

26 Tits-Dieuaide, Formation des prix céréaliers, 144-151.
} 
that-around 1550-more than half of the arable land was used for bread grain cultivation, with much of the produce consumed by the smallholders themselves. ${ }^{27}$

By that time, in large areas of Holland the cultivation of wheat and rye had become almost impossible. The peat lands that had rendered a satisfactory crop of bread grains for many years after their reclamation increasingly failed to do so, as the drained peat soil gradually subsided. Exactly when wheat and rye cultivation became problematic is still a matter of debate-perhaps as early as 1350 , but certainly by the early 15th century. ${ }^{28}$ With the exception of a few regions with sandy or clay soils-such as the South-Holland islands, the Honterland (the region west of Delft), the Gooiland, and parts of West-Friesland-Holland could no longer survive without importing bread grains. Even around the year 1400, Holland grain merchants were buying large quantities of grain in the ports of the Somme region. They also visited the grain markets in the cities of the southern Low Countries. ${ }^{29}$ French, Flemish and Brabant grain remained important in the 15th century, but Holland also imported substantial quantities of grain from other regions-from the German Rhineland and the upper Meuse region, from nearby Guelders, Utrecht and Zeeland, and from the north of Germany. Only at the end of the century did this diversity begin to give way to a growing dominance of the rye trade with the Baltic region, although this process was not completed until the middle of the 16th century. By then, Holland probably produced only 10 to $25 \%$ of the bread grain it needed, depending on imports for the remainder. ${ }^{30}$ As will be shown in the following pages, this dependence on grain imports had important effects. It probably gave rise to a pattern of price change over the year, deviating from what was customary in other countries, and it is likely that it stimulated interregional market integration.

A second non-institutional factor bound to affect market integration is the cost of transport. Its importance is clear from the fact that market integration in Europe jumped to a much higher level with the innovations in transport technology of the modern era. ${ }^{31}$ The possibility of

27 Thoen, Landbouwekonomie, 706-707, 840-842.

28 Van Bavel and Van Zanden, 'Jump-Start', 516-518.

29 Sneller, 'Hollandsche korenhandel', 165-166; Tits-Dieuaide, Formation des prix céréaliers, 167.

${ }^{30}$ Van Tielhof, Hollandse graanhandel, 63-75, 122-125; Van Tielhof, 'Grain Provision', 203-205.

31 Persson, Grain Markets, 91-113. 
another jump of this kind in the high Middle Ages cannot be excluded. Twelfth-century England, for example, witnessed a dramatic increase in the number of bridges and a transition from traction by oxen to traction by horses that may well have had a similar revolutionary effect. However, quantitative data from this period that would allow us to detect the consequences of such a jump for price integration are lacking, and from the 14th century onwards - when reliable data are available-transport costs appear to have changed very little. ${ }^{32}$

Even if no major revolution in transport costs took place in the late Middle Ages, the costs of transporting grain have a bearing on the analysis in the following pages for another reason: they are linked to the mode of transport. Calculations made by Masschaele, on the basis of data from a number of 14th-century English sheriffs' accounts, show that the ratio of the costs of land transport to river transport to sea transport was about 8:4:1. ${ }^{33}$ Medieval Holland, because of its location on the coast and in the delta of Rhine and Meuse, had easy access to transport by sea and by river. Moreover, the county was characterised by an extensive network of smaller inland waterways. This must have helped maintain low transport costs for grain.

Fragmentary data on internal transport costs support this assumption. In the year 1388/89, Egmond Abbey purchased wheat in Haarlem on several occasions. For three of these occasions, the accounts report transport costs to Egmond, a distance of 24 kilometres as the crow flies. These transports added on average $1.8 \%$, or $0.07 \%$ per kilometre, to the price the Abbey had paid for the wheat. About ten years later, functionaries of the count organised three large transports of wheat bought in Haarlem to Amsterdam, a distance of 17 kilometres. Each transport added about $1.0 \%$ to the average price of wheat in this year, or $0.06 \%$ per kilometre. Finally, when in 1432 the Catharinagasthuis in Leiden arranged for six small wheat transports between Delft and Leiden-a distance of 19 kilometres-the transport costs added on average $0.1 \%$ per kilometre to the price of the wheat. ${ }^{34}$ Masschaele's calculations of transport costs for wheat in 14th-century England arrive at an addition of $0.25 \%$ per kilometre for land transport; for river transport, the addition was just above $0.1 \% .{ }^{35}$ The Holland rates

\footnotetext{
32 Masschaele, 'Transport Costs', 276-277.

33 Ibid., 273.

34 Hof, Egmondse kloosterrekeningen, 101; Verwijs, Oorlogen van hertog Albrecht, 101, 103, 104; RAL AG, inv. no. 334-41 f 29, 29v, 30.

35 Masschaele, 'Transport Costs', 274, 277.
} 
just mentioned are around or below the latter figure, which is probably a reflection of the density of the network of waterways in Holland.

Both the early dependence on grain imports and low transport costs related to Holland's geographical situation may have stimulated market integration independently of the impact of favourable market institutions. This must be taken into account when comparing Holland with England or with the southern Low Countries. Here this will be undertaken in general terms only; developing a quantitative model that weighs the effects of institutional against non-institutional factors is beyond the scope of this study.

\subsection{Methods And Data}

Sophisticated methods for measuring price integration such as those used by Persson require continuous or almost continuous price series, a requirement the data from late 14th and early 15th-century Holland do not meet. ${ }^{36}$ Therefore, the analysis presented here is based on the simplest of methods. Price volatility, both within and between years, is assessed by calculating variation coefficients-in the first case over monthly and in the second over annual prices (the variation coefficient is the standard deviation as a percentage of the mean). Co-movement of prices is measured on the basis of correlation coefficients over annual prices. Unfortunately the nature of the sources does not allow for a detailed analysis of co-movement of prices on a regional level (within Holland). The analysis of price movements therefore focuses on the international level (the links between Holland markets and markets abroad). In order to preserve proportionality, prices have been converted to a logarithmic scale; to allow for interregional comparisons they have also been converted to grams of silver per hectolitre. ${ }^{37}$

The use of simple measures has disadvantages. Correlation coefficients may be influenced by something more than just market integration. High coefficients may also reflect similarities in weather conditions and thus in yields; likewise, low coefficients may, at least in theory, indicate local differences in yields. About the latter we need not worry too much: research results for the late Middle Ages suggest that

\footnotetext{
36 Persson, Grain Markets, 105, 114-115.

${ }^{37}$ I am grateful to Christiaan van Bochove for sharing his knowledge with me on the possibilities and problems involved in measuring market integration.
} 
local weather conditions did not have a strong impact on prices. According to Clark, in medieval England the connection between manorial yields and local prices was weak. For 65 manors Clark compares local yields in the 13th, 14th and early 15 th centuries to local prices. He finds that prices were only marginally influenced by local yields; instead, they conformed to a very large extent to a national trend. If local yields were high and prices threatened to fall, the surplus soon flowed out to markets where it fetched a better price, thus restoring local prices to average levels. If yields were low and prices high, grain would flow in-with the same effect. Clark estimates that, even when local yields doubled, local prices would still fall by only $2.5 \%{ }^{38}$

The possibility of adverse growing conditions prevailing in a large region over a longer period of time-for instance, in the case of a very dry or a very wet summer or, even worse, a series of consecutive bad years of this type-is another matter. ${ }^{39}$ In situations like these, prices on the whole would no doubt have moved upward even if markets had been isolated, accounting for part of the correlation. Yet prices would not have risen with the same speed and to the same level everywhere; there were bound to be local variations in supply and demand, and it would still depend on the degree of market integration whether these local variations were evened out or not. Therefore, correlation coefficients - if used with caution - can still be a helpful instrument of analysis in situations where more advanced methods are not applicable.

Price volatility, in whatever way it is measured, may also be influenced by more than just market integration. Softening of extremes through market regulation has already been discussed. In addition, there is a second factor that affects liberal markets as well as regulated ones: storage. Stored reserves of grain can level out deficits in much the same way as can transports from surplus to shortage regions. However, there is no reason to think that in Holland storage was much greater or lesser than in neighbouring regions. Carry-over of grain reserves from one year to the next appears to have been a marginal phenomenon everywhere. Although many people may have held on to a small grain reserve for their own use, as a safeguard against famine, grain prices were too unpredictable to induce merchants or farmers to stock large volumes from one year to the next as a profit-maximising strategy.

\footnotetext{
38 Clark, 'Markets and Economic Growth', 8-16.

39 For a discussion of the impact of such events on grain yields and grain prices, cf. Campbell, 'Nature as Historical Protagonist'.
} 
It was by no means certain that next year's grain prices would cover the costs of storage for a year. ${ }^{40}$

Producers and merchants did of course store grain after the harvest in order to sell it in the course of the year, but the costs-which included barn rent, the consequences of depreciation of the grain, and the opportunity costs of the interest foregone-would have been much the same everywhere. ${ }^{41}$ It is true that between 1380 and 1440 interest rates in Holland fell from about $10 \%$ to around $6.25 \%$, but they did much the same in England and in the southern Low Countries. ${ }^{42}$ In short, as long as measures assessing price fluctuations are used in a comparative approach, there is little reason to fear the results will be biased by differences in storage volumes.

Before the late 14th century, Holland grain price data are fragmentary, unreliable, or both. There are some prices in the early 14th-century comital accounts, but they are few and far between..$^{43}$ The year 1344/45 is an exception: thanks to war-time preparations, there are some references to wheat purchases in the comital accounts, and the account of Egmond Abbey over the same year-the oldest account in the Abbey's archive-provides several more. ${ }^{44}$ The Egmond accounts for the next couple of decades are missing, but the comital accounts have been preserved. De Boer has constructed series of wheat, rye, and oats prices in the second half of the 14th century based on the comital accounts for the central part of Holland. However, as De Boer himself admits, although these series indicate long-term price movements, they probably do not accurately reflect short-term market fluctuations, as they are based on the monetary valuations of annual grants or rents that had originally been in kind. ${ }^{45}$ This effectively rules out their use for a study of market integration.

Only at the end of the 14th and the beginning of the 15th century do the accounts of religious institutions begin to render real price series. Unfortunately, their geographical distribution is rather unbalanced.

\footnotetext{
${ }^{40}$ Persson, Grain Markets, 55-62, 67-72.

${ }^{41}$ McCloskey and Nash, 'Corn at Interest', 178.

${ }^{42}$ Zuijderduijn, Medieval Capital Markets, 283-285. On interest rates in other countries in Europe, see Epstein, Freedom and Growth, 61-62, and Clark, 'Cost of Capital', 273-274.

${ }_{43}$ Hamaker, Rekeningen grafelijkheid I, 70-72 (1317), 140 (1331), 248 (1342/43); II, $89(1343 / 44)$.

${ }^{44}$ Ibid. II, 161, 415; Hof, Egmondse kloosterrekeningen, 39-42.

${ }^{45}$ De Boer, Graaf en grafiek, 196-200; cf. 192-194.
} 
From the northern part of Holland, there is only a very short series of wheat prices from Egmond Abbey, covering the years 1387/88 to $1391 / 92$. The only other two price series available before the late 15th or even the early 16th century are from the Rijnland region in the central part of Holland: the prices of the Catharinagasthuis in Leiden from the year 1392/93 onwards and the price series of Leeuwenhorst Abbey in Noordwijkerhout (about 11 kilometres north of Leiden) beginning in the year 1410/11. Each of these sources is briefly discussed below; Appendix D provides more detail and also presents the annual average prices calculating from the sources.

Egmond Abbey, situated in the north of the county, was Holland's oldest religious institution, but the surviving records give wheat prices for only five years at the end of the 14th century. These prices are usually based on just two or three entries in the accounts. Moreover, it is not entirely clear if these entries reflect market prices. It is not impossible that, in years of dearth, Egmond Abbey could make use of its position as a powerful landowner to obtain grain below market prices. We know that in the middle of the 14th century Egmond Abbey still partly relied on its own barley production: the account over the year 1344/45 mentions barley being taken to Egmond from the nearby villages of Ouddorp and Oterleek in West-Friesland (although barley from distant Texel was sold locally). ${ }^{46}$ The late 14th-century accounts no longer mention grain shipments from Ouddorp and Oterleek, but they do show that at least occasionally some of the land rents were paid in kind. ${ }^{47}$ For these reasons, the Egmond prices have not been included in the analysis, although for the sake of completeness and future reference the data have been incorporated in Appendix D.

The Catharinagasthuis and Leeuwenhorst price series span longer periods of time, although both have gaps. Prices until the year $1439 / 1440$ were collected anew from the original accounts. This year was selected as the final year because this permits a full analysis of the interesting events during the dearth years 1437 to 1439 . For both series, checking the originals led to the correction of several mistakes-some of them rather serious-in the published annual figures. ${ }^{48}$

\footnotetext{
${ }^{46}$ Hof, Egmondse kloosterrekeningen, 20; the shipping costs for bringing grain from Frisia on page 33 probably refer to the transport from Ouddorp and Oterleek as well.

${ }_{47}$ Noord-Hollands archief, Archief van de abdij van Egmond, inv. no. 798, f 105v, $143,153 \mathrm{v}$.

${ }^{48}$ For the sources and source editions, see Appendix D.
} 
The Leeuwenhorst figures probably reflect market prices most accurately. The Abbey frequently made purchases of wheat; added up over the year, quantities were sizable. The Abbey owned land in some of the areas where bread grain production was possible: the sandy coastal strip and the Honterland. It had its own farm and may, especially in times of dearth, have produced part of its own rye. This would explain why, during the later decades of the 15th and the first decades of the 16th century, the accounts do not mention rye purchases. ${ }^{49}$ For wheat, however, there are no such gaps; even in times of extreme dearth, the Abbey continued to buy wheat. Until the year 1430/31, the entries in the accounts are usually dated. The dates demonstrate that purchases were distributed fairly evenly over the year. The accounting year begins in August and ends in July, approaching the ideal of an accounting year that coincides with the harvest year.

The Catharinagasthuis (St. Catherine's hospital) was an urban hospital that provided food and shelter-originally to poor travellers, but in the late 14 th and early 15 th century mainly to the sick and dying. ${ }^{50}$ The Catharinagasthuis series has the advantage of starting almost twenty years earlier than the Leeuwenhorst prices, but on the other hand wheat purchases were less frequent and total volumes were smaller. Still the Catharinagasthuis probably bought all its bread grains; it rented out its agrarian land and there is nothing in the accounts to suggest rent payments were ever requested in kind. ${ }^{51}$ Unfortunately, the accounting year of the Catharinagasthuis, beginning and ending at St. Peter ad Cathedram (February 22), covers parts of two harvest years. Conversion to harvest years is not possible because the dates of the transactions have almost never been noted, limiting possibilities for a fruitful comparison with other price series.

Despite their large demand for wheat, we can be fairly sure Leeuwenhorst Abbey and the Catharinagasthuis did not dominate the market to the extent that they were able to dictate prices. Both the Abbey and the Catharinagasthuis bought some of their wheat at the weekly markets of Leiden ('op die grote brugghe', at the large bridge)

${ }^{49}$ De Moor, Lonen en prijzen, 32-33.

${ }^{50}$ Ligtenberg, Armezorg, 19-20, 31.

${ }^{51}$ The possibility that this did happen cannot be discarded until a satisfactory explanation has been found for the near absence of rye purchases: it is almost beyond belief that a hospital and guesthouse for the poor would have supplied its patients and guests with nothing but wheaten bread. 
and, in the case of Leeuwenhorst, also in Delft. ${ }^{52}$ Many transactions took place outside official market hours, but these probably conformed to regular market conditions. Leeuwenhorst, for example, usually did business with a number of merchants all over the region, which makes it unlikely the Abbey was able to influence prices. ${ }^{53}$ In Leiden there is, at first sight, more reason for suspicion. Several of the grain merchants with whom the Catharinagasthuis did business can be identified as members of the Leiden elite, and some of them (Dirc Poes Pietersz., Gerrit of Oestgheest, and Wermbout Kerstantz.) were-or had beenalso members of the hospital board. ${ }^{54}$ Moreover, in some years the hospital obtained most of its wheat from just one merchant. In theory, this kind of relationship could have led to pre-arranged price agreements or other deviations from the market mechanism, but the accounts suggest this was uncommon.

For instance, in only two years the hospital bought all of its wheat from one cornmonger, and both these years date from the $1390 \mathrm{~s}^{55}$ Afterwards, there were no exclusive monopolies, although between 1414 and 1419 the greater part of the wheat deliveries came from one merchant: first from Dirc Poes Pietersz., then from Wermbout Kerstantz. Moreover, even when there was a preference for a specific merchant, purchases were often valued at different prices, obviously following seasonal fluctuations in market price. The year 1417 is a good example. In this year the Catharinagasthuis made several purchases of wheat from Dirc Poes Pietersz, for prices starting at a little over 19 groot per achtendeel and falling stepwise to just under 12 groot at the end of the accounting year. ${ }^{56}$ It is therefore safe to assume that, with the possible exception of the first decade, the Catharinagasthuis price series reflect market prices fairly accurately.

In order to gain insight into interregional market integration, Holland prices must be linked to similar price series in neighbouring regions. Nearby Utrecht renders wheat price series starting in 1370, based on

\footnotetext{
52 E.g. RAL AG, inv. no. 334-6 f 13, 334-27 f 25, 334-37 f 24; NA AAL, inv. no. 23 f $2 \mathrm{v}, 26 \mathrm{f} 2 \mathrm{v}, 31 \mathrm{f} 2$.

53 De Moor, Lonen en prijzen, 33.

54 Poes Pietersz. was gasthuismeester in 1413, Van Oestgheest in 1424 and Kerstanz. in 1418-1420 (RAL AG, inv. no. 334-27/28/30). Cf. Van Kan, Sleutels tot de macht, $83,88,231,267-268$.

55 RAL AG, inv. no. 334-2 f 11 (1384) and 334-3 f 9v (1396). However, there are a few years in which not all entries mention the name of the seller.

56 RAL, AG inv. no. 334-25 f 25v.
} 
the accounts of the chapters of the Dom Church and the chapter of St. John. The Dom Church accounts also provide recordings of market prices per month, used to determine the canons' monthly provisioning allowance. In the past, the late 15th- and 16th-century Utrecht monthly grain prices have sometimes been used as proxies for Holland grain prices, based on the argument that the Utrecht and the Holland markets were closely related. ${ }^{57}$ This approach has not been copied here, not only because until the late 15 th century these monthly recordings are scarce, but also because of a more fundamental argument: if Holland market institutions really made a difference to the level of market integration, using Utrecht prices will not bring it out. Therefore, the Utrecht prices have been included in the analysis of interregional integration. Appendix D gives more information on the Utrecht price data and on the rather complicated conversion of Utrecht currency to silver. For Maastricht, situated on the Meuse in the southeast of the present-day Netherlands, annual wheat prices are available from 1342 onwards. The chapters of St. Servatius and Our Lady jointly recorded the market price in Maastricht around the first of July of each year to use it as a basis for the conversion of rents in kind into cash payments. ${ }^{58}$

In Flanders, the earliest wheat price series are those of St. Donatian's chapter in Bruges, starting in 1348/49. For the 15th century, we also have an incomplete series of wheat prices from four religious institutions in Ghent, starting in 1400/01. For Brabant, there are price series of the hospitals of the beguinages in Brussels and Louvain, starting in 1400/01 and 1403/04 respectively. All these prices are institutional prices subject to the same limitations as the Catharinagasthuis and Leeuwenhorst price series, but for Louvain and Brussels-and to a lesser extent also for Ghent-there is an extra handicap: in part, the data are based not on market prices but on grain rents converted into cash. Although at least for Louvain there is enough evidence to prove

${ }^{57}$ Noordegraaf, Hollands welvaren, 15-17; Van Tielhof, Hollandse graanhandel, 31.

${ }_{58}$ Tijms, Prijzen van granen, 25-47. For the conversion of prices into silver, I have used Table 6 on page 77. This conversion results in prices that between about 1420 and 1443 , when Maastricht currency was revalued, are consistently higher than elsewhere; clearly the official rate no longer corresponded with the actual value. This may to some extent have influenced results, although the measures that have been used are not very sensitive to this kind of bias. 
that in normal years these prices closely followed the market, in years of dearth this may not always have been the case..$^{59}$

For England use has been made of two well-known price series. The Exeter prices published by Beveridge are urban market prices, recorded by the Exeter authorities in order to set the Assizes of Bread (that is, to fix the weights of bread to be sold for a certain price). The prices published by Rogers are often referred to as London prices, but strictly speaking they are sales prices collected from the accounts of a large number of manors. Nevertheless, since most of these manors are situated in the counties around London and since research has shown these counties to have been part of a coherent grain market, the use of the Rogers series as a representation of wheat prices in the London region is acceptable. Both the London region prices and the Exeter prices are available from a very early date onwards. ${ }^{60}$

\subsection{Price volatility}

The concept of volatility covers both seasonal price fluctuations and fluctuations in prices from one year to the next. A detailed study of the first requires high-quality data: preferably monthly prices, but at least frequent and dated entries distributed over the year. For early 15th-century Holland, data of this kind are very scarce. The entries of grain purchases in the Catharinagasthuis accounts are undated; those in the Leeuwenhorst accounts are dated only for the first two decades of the series, that is for a total of 13 years between 1410/11 and $1430 / 31$.

${ }_{59}$ Verlinden, Dokumenten II, 34-36 (Bruges; also available online (IISH, 'Database of Historical Prices and Wages')); Verlinden, Dokumenten I, 36-37 (Ghent; cf. Okunishi, 'Grain Price Fluctuations', for a critical discussion of the quality of the Ghent data); Tits-Dieuaide, Formation des prix céréaliers, 269-271, 15-16 (Brussels and Louvain). The accounting year of the Bruges and probably also the Ghent series runs parallel with the harvest year, that of the Brussels and Louvain series begins and ends in May or June. Conversion of the Flemish and Brabant currency into silver has been based on Van der Wee and Aerts, 'Vlaams-Brabantse muntgeschiedenis', 83-84.

${ }^{60}$ Beveridge, 'Statistical Crime' (Exeter); Rogers, History of Agriculture and Prices (London). Both are also available online: Allen and Unger, 'Allen-Unger Database European Commodity Prices 1260-1914'. The accounting year of both series runs parallel with the harvest year. Conversion of the English currency into silver has also been based on the Allen-Unger Database (originally derived from Feavearyear, The Pound Sterling). On the London region grain market, see Campbell et al., Medieval Capital. 
There are two ways in which these Leeuwenhorst data can be used to study the development of wheat prices within the year. The first follows the method devised by McCloskey and Nash. In order to estimate storage costs, McCloskey and Nash used pairs of prices to calculate an annual price change rate in late 13th- and 14th-century England. In the absence of reliable series of monthly prices, they collected a large number of price pairs-prices from two different months in the same year and in the same location. By combining these, they arrived at an average seasonal increase of around $30 \%$ or more on the September price ${ }^{61}$ This method has been replicated and extended to later time periods by Nicholas Poynder, who has drawn two conclusions from the findings: firstly, after the 14th century a very significant drop in seasonal increase took place (for the 15th and the first half of the 16th century, Poynder arrived at a change rate of only 9\%); and secondly, this could not have been caused only by the decline in storage costs due to falling interest rates. Poynder claims institutional factors also contributed: in the 14th century, seasonal increase was very high because large-scale grain production was inefficient and merchants paid high transaction costs to obtain grain stocks. ${ }^{62}$

The application of the McCloskey and Nash method to the Leeuwenhorst prices over the years $1410 / 11$ to $1430 / 31$ leads to a surprising outcome: instead of rising in the course of the year, between September and July wheat prices fell by an average of $0.7 \%$ per month or $7.5 \%$ over the entire period. ${ }^{63}$ This may be a coincidence; the sample is, of course, very small. However, evidence from Bruges suggests there is more to it than that. The Bruges series gives prices for three moments in the year: November 11, February 2, and Ascension Day. In the second and third decade of the 15th century a downward trend is also visible here: in the six months between November 11 and Ascension Day, Bruges wheat prices fell on average $2.7 \%$ (or $2.1 \%$ if the comparison is restricted to the same 13 years that are covered by the Leeuwenhorst data). In Bruges this is clearly not a temporary phenomenon. A downward seasonal trend can also be demonstrated for the years before 1410 and after 1430, and in fact for the early modern era

${ }^{61}$ McCloskey and Nash, 'Corn at Interest', 178-179.

62 Poynder, 'Grain Storage', 6.

${ }^{63}$ The month of August has not been included because there are only very few observations in this month. If figures are converted to a logarithmic scale and the change rate is calculated over the entire year, as is done by McCloskey and Nash, the figure is $8.7 \%$. 
as well. However, both in Utrecht-which has monthly prices for 23 scattered years between the early 15 th and the early 16 th century-and in the Brabant town of Lier-with fairly complete monthly prices from 1433 onwards - seasonal fluctuations on average move upward instead of downward, with rates not very different from the change rate for England calculated by Poynder. ${ }^{64}$ The figures are summarised in Table 4. There is no way to explain price falls in the course of the year by storage costs alone, whatever their level; if anything, this proves that Nicholas Poynder is correct in claiming that seasonal fluctuations were not determined just by storage.

Table 4 Seasonal increase or decrease of wheat prices in selected locations and periods

\begin{tabular}{llllc}
\hline & $\begin{array}{l}\text { Seasonal } \\
\text { increase/ } \\
\text { decrease }\end{array}$ & Calculated over & Period & $\begin{array}{l}\text { Number } \\
\text { of years }\end{array}$ \\
\hline Noordwijkerhout & $-7.5 \%$ & September - July & $1410 / 11-1430 / 31$ & 13 \\
Bruges & $-4.4 \%$ & Nov 11 - Ascension Day & $1348 / 49-1409 / 10$ & 56 \\
& $-2.7 \%$ & Nov 11 - Ascension Day & $1410 / 11-1430 / 31$ & 19 \\
& $-1.0 \%$ & Nov 11 - Ascension Day & $1431 / 32-1500 / 01$ & 67 \\
Utrecht & $-3.2 \%$ & Nov 11 - Ascension Day & $1501 / 02-1700 / 01$ & 180 \\
Lier & $+7.6 \%$ & October - July & $1401 / 02-1507 / 08$ & 23 \\
England & $+5.4 \%$ & September - July & $1433 / 34-1499 / 00$ & 43 \\
\hline
\end{tabular}

Sources: see Appendix D (Noordwijkerhout, Bruges and Utrecht); Tits-Dieuaide, Formation des prix céréaliers, 282-284 (Lier); Poynder, 'Grain storage', 6 (England).

In order to throw some more light on the backgrounds to seasonal grain price fluctuations in Holland, the Leeuwenhorst price data have also been processed in a second way. Figure 11 shows the development of wheat prices between September and July as a percentage of the average price in that year. The graph suggests prices fell in autumn, recovered partially in the winter months, and then continued to fall until the summer, when they rose sharply. Without more detailed research, it is not possible to come up with a conclusive explanation for this pattern. Here, no more than a hypothesis-and a tentative one at that - can be ventured. It links up with the fact that both Bruges and

${ }^{64}$ The Lier monthly grain prices have been published by Tits-Dieuaide, Formation des prix céréaliers, 282-284. 


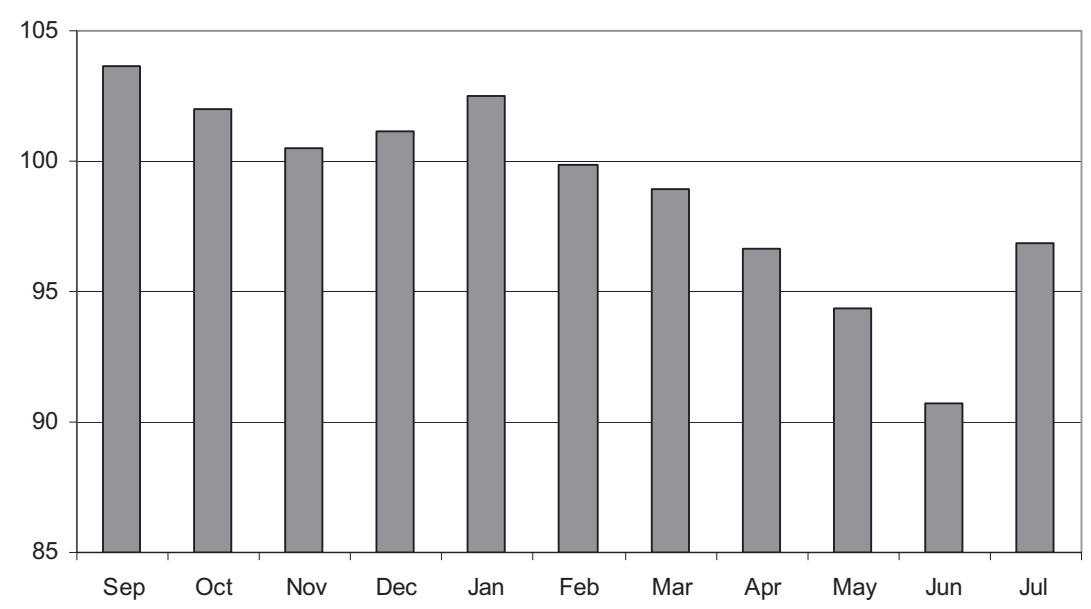

Figure 11 Monthly wheat price between September and July in the accounts of Leeuwenhorst Abbey, as a percentage of the annual wheat price; averages over the years 1410/11-1430/31

Source: see Appendix D

Holland were, to a large extent, dependent on grain imports. Grain supplies may have reached markets only gradually in the course of the year. As a result, prices would not have experienced a sudden drop around harvest time as a result of large quantities of grain arriving on the market simultaneously, as happened in grain-producing regions. Instead, they declined much more slowly, in parallel with the continuous arrival of grain throughout the year. In winter, this process may have been suspended as shipping temporarily came to a halt because of the weather; in summer, merchants may have preferred to postpone their next trip to the production areas until the new harvest was in and prices had fallen.

The evidence on seasonal fluctuations remains inconclusive, if only because of the scarcity of detailed price data for the early 15th century. Fortunately, an analysis of price volatility between the years is more manageable: annual averages, or prices recorded on the same date every year, are more widely available.

Figure 12 compares the variation coefficients per decade derived from the price series of the Catharinagasthuis and Leeuwenhorst Abbey with those calculated for the eastern Low Countries, the southern Low Countries, and England. The results for the Catharinagasthuis and Leeuwenhorst Abbey, although at the low end of the 


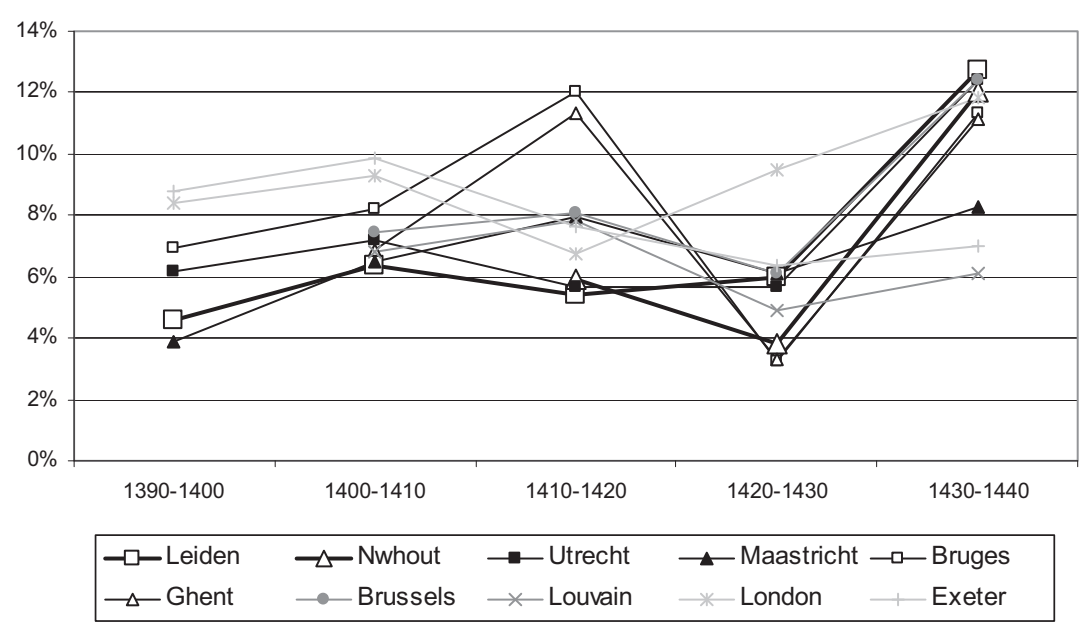

Figure 12 Variation coefficient of logs of annual average wheat prices (in grams of silver per hectolitre) per decade in Leiden, Noordwijkerhout, and eight other locations in the Low Countries and England, 1390-1440

Sources: see Appendix D

international spectrum, are within 'normal' range. The figures for the Catharinagasthuis may, moreover, have been underestimated: amplitudes may well have been dampened by the fact that each accounting year covers parts of two consecutive harvest years, and for the first decade perhaps also by pre-arranged price agreements with a single merchant.

Extreme price fluctuations in the 1430 s are directly related to the severe grain shortages in the years 1437 to 1439 . These years were marked by rapidly rising grain prices in large parts of Europe, probably caused by widespread harvest failure ${ }^{65}$ It is worthwhile examining this crisis in some more detail. In these years, the authorities in Holland intervened in the grain trade on an unprecedented scale, laying the foundations for increasingly intensive dearth policies in the late 15th and early 16 th

${ }^{65}$ Ibid., 224-228. Tits considers the grain export embargo imposed by the Hansa towns to be the major cause for the crisis of 1437-1439, but later research has shown that at that stage, both in Holland and in Flanders, Baltic imports were minor in comparison to imports from northern France (Van Tielhof, Hollandse graanhandel, 122125; Dambruyne, Mensen en centen, 318-320). Moreover, at that time extreme dearth was also reported in France, England, and the German lands (Irsigler, 'Getreidepreise', 588-589). 
centuries. ${ }^{66}$ Some of the reactions to the crisis were predictable. In Leiden, for instance, bakers and grain merchants were forbidden to buy grain at the weekly market, and market hours for consumers were reduced. ${ }^{67}$ In Brielle, there were export prohibitions on grain and beer, prohibitions against buying and selling grain before market hours, and limitations on the amount of grain people could buy per week. ${ }^{68}$ Other towns went further and began buying grain themselves: Gouda sent the town clerk Dirc Sonderdanc to Amsterdam to purchase 100 last of grain, and Rotterdam bought 15 last of 'old' wheat and rye in the same city. ${ }^{69}$

Most striking, however, are the interventions of the central government, after extensive deliberations with the representatives of the towns. In September 1437, a general export prohibition on grain was proclaimed; beer could be exported only if, in return, a certain amount of grain was imported. In October even more drastic measures were announced-so drastic, in fact, that their implementation can hardly have been successful. All grain prices were to be fixed at a certain maximum (for wheat this was 21 to 24 groot per achtendeel, depending on origin and quality); in addition, in every town and village the entire grain trade was to be put into the hands of small groups of cornmongers, who were to receive instructions from government officials about how much grain each of them should buy and sell within a certain period. $^{70}$

The effects of these policies are questionable, to say the least. In the Leeuwenhorst accounts, wheat prices of more than twice the official maximum can be found (the highest price recorded is 56 groot per achtendeel), and there are no signs of the number of suppliers being limited. In fact, the opposite is the case: the Abbey appears to be buying many small amounts of wheat from a large number of sellers against rapidly mounting prices. Everything suggests distress. Admittedly, this was also the case in the neighbouring regions, but

${ }^{66}$ Van Schaï, 'Prijs- en levensmiddelenpolitiek', 247.

67 Hamaker, Middeleeuwsche keurboeken Leiden, 506-507.

${ }_{68}$ De Jager, Middeleeuwsche keuren Brielle, 177-180. These regulations are incorporated in a collection of by-laws officially recorded in 1445, but most likely date back to the crisis of the previous decade.

${ }^{69}$ Heinsius, 'Oudst-bewaarde stadsrekening van Gouda', 281 (Gouda); De Blécourt and Meijers, Memorialen Rosa II, no. 500 (Rotterdam).

${ }^{70}$ Van Limburg Brouwer, Boergoensche charters, 37-39; Unger, 'Hollandsche graanhandel', 464-465, 490-491; Van Schaïk, 'Prijs- en levensmiddelenpolitiek', 227. 
Holland appears to have been hit hardest. Table 5 displays wheat prices in the years $1437 / 38$ and $1438 / 39$ as a percentage of the average wheat price in the ten years preceding the crisis; Figure 13 shows the actual development of wheat prices in this period in graphic form. ${ }^{71}$

Table 5 Annual wheat prices in 1437/38, 1438/39, and 1439/40 as a percentage of average annual prices over the years $1427 / 28$ to $1436 / 37$ in Holland, Flanders, Brabant, and England

\begin{tabular}{llc}
\hline & \multicolumn{2}{l}{ Price relative to average price 1427/28-1436/37 } \\
\cline { 2 - 3 } & In $1437 / 38$ & In $1438 / 39$ \\
\hline Noordwijkerhout & $241.9 \%$ & $264.6 \%$ \\
Bruges & $212.4 \%$ & $247.8 \%$ \\
Ghent & $177.3 \%$ & $219.4 \%$ \\
Brussels & $129.1 \%$ & $215.8 \%$ \\
Louvain & - & $149.7 \%$ \\
London & $153.0 \%$ & $240.2 \%$ \\
Exeter & $156.8 \%$ & $185.9 \%$ \\
\hline
\end{tabular}

Sources: see Appendix D



Figure 13 Annual average wheat prices (in grams of silver per hectolitre) from 1427/28 to $1439 / 40$ in Holland, Flanders, Brabant, and England Sources: see Appendix D

${ }^{71}$ The figures for Leiden, Utrecht and Maastricht have not been included. The Leiden series misses the years 1437/38 and 1438/39; the Utrecht and Maastricht series both miss 1438/39. 
The table and graph both suggest that Holland was vulnerable to dearth: of all locations, Noordwijkerhout displays the highest price peak. Although for the Catharinagasthuis the years 1437/38 and $1438 / 39$ are missing, the account for 1439/1440-which in the case of the Catharinagasthuis covered spring and summer of the harvest year $1438 / 39$ as well as the autumn and winter following the good harvest of 1439 -gives a price that is $204.5 \%$ over the level of the preceding ten years. This suggests that Leiden wheat prices during the crisis were also very high.

The fact that Bruges also had serious problems-price rises in Bruges are second only to those in Holland-conforms with a pattern described by Unger, who points out that coastal regions witnessed greater price fluctuations than towns located on rivers that gave them access to a variety of suppliers. ${ }^{72}$ Price increase and price volatility in Ghent, Brussels, and particularly in Louvain were indeed more moderate than in Holland or Bruges. Unger concludes that interregional (i.e. overseas) integration was weak; however, this is not necessarily true. For one, the figures for the Brabant towns may have been flattered by the fact that prices for these towns, and to a lesser extent also for Ghent, were in part derived from monetary valuations of rents, which in a time like this may very well not have followed the market. For Louvain, in particular, there is cause for suspicion: it is hard to believe that Louvain market prices during the crisis should have been so much lower than prices elsewhere in the region. In addition, Ghent may-as suggested earlier-have profited from its grain staple and the rigid regulation of the grain trade. This may have taken the edge off price extremes.

More fundamentally, the dependence of Holland and also of Bruges on imports probably contributed to higher-than-average price spikes in years of scarcity. Under these conditions, the authorities in exporting regions were likely to attempt to minimise exports, whereas in the importing regions the effects of actual scarcity may well have been exacerbated by uncertainty and fear about future grain supplies. It is worth noting that in London and especially in Exeter-both in coastal districts but not nearly as dependent on imports-the crisis of 14371439 did not hit as hard as in Holland or in Bruges: prices did not rise to the same heights. In itself this does not prove much; harvests in

72 Unger, 'Feeding Low Countries Towns', 338. 
England, or at least in the West Country, may simply not have been quite as disastrous as on the continent. However, it does make clear that we should not jump to conclusions about the level of market integration based on price volatility alone.

\subsection{Price integration}

Additional information can be gleaned from a study of the integration of prices: the degree to which prices in different locations move in concert. For 16th-century Holland, some research on price integration has been conducted: Cornelisse, for instance, has investigated differences in peat prices in various towns in the central part of Holland, and Noordegraaf has compared the trends in Leiden and Utrecht grain prices. ${ }^{73}$ Both authors come to the conclusion that-from at least the middle of the 16th century-markets displayed a considerable degree of integration, but their studies lack a comparative perspective and do not cover the period before the 16th century in any detail. Unger's recent attempt to measure market integration in the North Sea region by studying price correlation focuses on the 15th century and has a clear interregional component; but as far as Holland is concerned, the fact that Unger uses only the Leiden price series-with their deviating year of account-diminishes the validity of his conclusions. ${ }^{74}$ Here the more reliable Leeuwenhorst data have been used to monitor the comovement of prices between Holland and the neighbouring regions in the early 15 th century. First, however, we will take a brief look at some snippets of information bearing on Holland's internal grain market.

In May, June, and July 1398 the count of Holland sent out two purveyors to purchase large quantities of wheat as provisions for a military campaign against the Frisians. The records of these purchases in combination with the accounts of the Catharinagasthuis over the same year provide a first, very cursory glance at price integration within Holland. In total, the purveyors bought 914 hoed of wheat-most of it in Haarlem-at a price of 9.4 groot per achtendeel on average. ${ }^{75}$ In the

${ }^{73}$ Cornelisse, Energiemarkten, 205-219; Noordegraaf, Holland's welvaren, 15-17.

${ }^{74}$ Unger, 'Thresholds for Market Integration'.

${ }^{75}$ Verwijs, Oorlogen van hertog Albrecht, 101-106. Of the 914 hoed, 100 hoed was bought not in Haarlem but in Schoonhoven. However, the price of these 100 hoed is rendered in combination with costs for measuring and other expenses and can therefore not be used in the calculations. 
same year, the Catharinagasthuis paid an average price of 10.3 groot per achtendeel for its wheat in Leiden. ${ }^{76}$ Taking the difference in measures into account (the Haarlem achtendeel was about $6 \%$ larger than the Leiden achtendeel), the Haarlem price was no more than 3\% above the Leiden price.

Of course, it is impossible to draw conclusions about the level of market integration from this single comparison of prices. However, in combination with the ease with which the count's functionaries were apparently able to buy large quantities of grain within a limited period of time, it does at least suggest that-even at the end of the 14th century-Holland wheat markets were not isolated or primitive. This suggestion is supported by De Boer's analysis of a late 14th-century poem by the moralist poet, Willem of Hildegaersberch. The poem deals with the misdemeanours of some Parisian cornmongers who, through speculation and even sorcery, tried to corner the market. As De Boer explains, Van Hildegaersberch clearly assumed that his Holland audience was familiar with grain merchants buying up stocks of grain before harvest and with practices like regrating and forestalling. ${ }^{77} \mathrm{In}$ fact, we have already seen that the Leiden by-laws of 1406 attempted to regulate forward trading of grain. Forward transactions in anticipation of the harvest existed even in Antiquity; in the Middle Ages, they were known both in southern and northwestern Europe, as were attempts to regulate the practice. ${ }^{78}$ Nevertheless, the fact that forward trade was also practised in Holland indicates that, despite the late rise of trade and towns, here too a mature grain market had developed by the end of the 14th century.

As mentioned above, early 15 th-century price data for the northern part of Holland are lacking; all prices we have for this period come from the district around Leiden. A close connection between prices paid in this small region is to be expected. An analysis of the wheat prices paid by the Catharinagasthuis and Leeuwenhorst Abbey confirm this expectation. Since the accounts of the Catharinagasthuis run from February 22 to February 22 in the following year and the

${ }^{76}$ See Appendix D.

77 De Boer, 'Vanden Corencopers', esp. 138.

78 Poitras, Early History of Financial Economics, 338-340 (Antiquity); Peyer, Zur Getreidepolitik, 28 (13th-century Verona and Parma); Hermesdorf, Rechtsspiegel, 387 (late 14th-century Breda); Van Tielhof, Hollandse graanhandel, 215-222 (16th-century Amsterdam). 
Leeuwenhorst accounts from August to July, a comparison requires the time gap to be bridged. This has been achieved by using only the dated Leeuwenhorst entries and regrouping them according to the Catharinagasthuis accounting year. Two provisos apply. Where the Leeuwenhorst series is discontinuous, as it frequently is between 1410 and 1420, data are concentrated in just a few months of the year. Moreover, after the year 1430/31, regrouping proved impossible because the Leeuwenhorst accounts no longer give dated entries. Figure 14 compares, in graphic form, the development of average annual prices paid by both institutions. It shows that prices moved indeed in close concert.

In the absence of additional price data, a qualitative analysis of the market behaviour of the Catharinagasthuis and Leeuwenhorst Abbey can help to illustrate how the local Leiden market was integrated in a wider regional market; it also indicates how the Leiden market was connected to markets in other parts of Holland and to production areas both in Holland and abroad. Leeuwenhorst Abbey bought part of its wheat in nearby Leiden, or at least from merchants living there. A few names actually come up in both sets of accounts: Gerrit of Oestgheest and Dirc Poes Pietersz., for instance, delivered wheat to



Figure 14 Annual average wheat prices (in groten per achtendeel) paid by the Catharinagasthuis and Leeuwenhorst Abbey, 1410/11-1430/31

Sources: see Appendix D 
Leeuwenhorst as well as to the Catharinagasthuis. ${ }^{79}$ But whereas-at least until the 1430s-the Catharinagasthuis obtained almost all of its wheat in Leiden and most of it from Leiden merchants, the Abbey also did business with merchants from various villages in the Rijnland region. Moreover, from the beginning of the price series, Leeuwenhorst regularly purchased wheat from what were presumably farmers in Delfland-more specifically, the wheat-growing region west of Delft. In addition, the Abbey bought wheat in the town of Delft itself, either from unidentified persons at the weekly market (upt straet, in the street) or from merchants based there. ${ }^{80}$ This was something the Catharinagasthuis began to do in earnest only after 1430, perhaps because by that time the quantity of wheat the hospital needed had increased sufficiently to make the journey worthwhile.

A significant portion of the wheat on sale in Leiden and particularly in Delft probably came from the surrounding countryside. Three purchases by the Catharinagasthuis of Poelscer or Poeldijx tarwe (wheat from Poeldijk, a village near Delft) confirm this ${ }^{81}$ But Leiden was also visited by merchants from Gouda and Schoonhoven; they are mentioned repeatedly in the accounts of the Catharinagasthuis. ${ }^{82}$ References to merchants from the northern part of Holland (i.e. from Haarlem, Amsterdam, and Monnickendam) are less frequent and tend to be concentrated in a few years-no doubt years when price differentials were large enough to make the journey worthwhile. ${ }^{83}$ Although it was of course much smaller, in this respect the Rijnland grain market resembles the grain market in the London region as it has been described by Bruce Campbell and co-authors. In normal years, most of the grain London needed came from a core provisioning zone with a radius of 30 to 50 miles - whereas in years of dearth, purchases were made over a much greater distances. ${ }^{84}$

${ }^{79}$ E.g. NA AAL, inv. no. $19 \mathrm{f} 2 \mathrm{v}-3,20 \mathrm{f} 2 \mathrm{v}$. Nelle Poes, who frequently sold wheat to the Abbey from 1418/19 onwards, was probably the widow or daughter of Dirc Poes (De Moor, 'Leveranciers', part 1, AL 320.).

${ }^{80}$ E.g. NA AAL, inv. no. $23 \mathrm{f} 2 \mathrm{v}, 25 \mathrm{f} 2 \mathrm{v}, 26 \mathrm{f} 2$.

${ }^{81}$ RAL AG, inv. no. 334-41 f 29 and 29v, inv. no. 334-43 f 27;

${ }^{82}$ E.g. RAL AG, inv. no. 334-6 f 13, 334-9 f 13v-14, 334-11 f $14 \mathrm{v}, 334-12$ f 13 , 334-17 f 20, 334-31 f 20, 334-34 f 21v.

${ }^{83}$ RAL AG, inv. no. 334-17 f 20 (four different Haarlem merchants in 1412), 334$39 \mathrm{f} 24$ (a 'man from Amsterdam' in 1426), 334-41 f29 (a merchant from Monnickendam in 1432).

${ }^{84}$ Campbell et al., Medieval Capital, 63-76. 
Apart from a single appearance by an Utrecht merchant and one purchase of 'eastern' wheat, the Catharinagasthuis accounts do not directly refer to imports. ${ }^{85}$ Nevertheless, part of the grain was no doubt imported-for instance, by a man like the Leiden merchant Floris Paedse, who frequently sold wheat to the Catharinagasthuis and is probably the same person as Florent Page, one of the Holland merchants involved in a conflict about the export of grains from Abbeville in $1409 .{ }^{86}$

Considering the proximity of the Catharinagasthuis to Leeuwenhorst Abbey and the fact that they bought part of their grain at the same markets (and sometimes even from the same merchants), it is not surprising to find that prices were closely linked. Using the same regrouped data as above, the correlation coefficient of the logs of wheat prices in the accounts of the two institutions can be calculated at 0.879 . This is high, but nothing out of the ordinary. Over the same two decades, the correlation coefficients for the markets of Brussels and Louvain (24 kilometres apart) and Bruges and Ghent (40 kilometres apart) were in the same range: they can be calculated at 0.829 and 0.889 respectively. In fact, for towns and villages situated this close together, similar levels of integration have also been demonstrated for late 18th-century India. ${ }^{87}$

In summary, the price correlation between the Leeuwenhorst and the Catharinagasthuis figures tells us very little about the level of market integration within Holland in comparison to internal integration in other regions. Data that would allow for a study of the correlation between grain markets in the Rijnland region and grain markets in other part of Holland are simply lacking. In order to discover how Holland compared with the neighbouring regions with regard to market integration, a different approach is required: links between Holland markets and markets abroad have to be examined.

Because the accounting year of the Catharinagasthuis does not coincide with the harvest year, the Leeuwenhorst figures are the best guide to the position of Holland in the interregional wheat market of northwestern Europe. For the years 1410/11-1430/31, correlation coefficients have been calculated for in total 36 pairs of locations: all imaginable combinations between Noordwijkerhout (Leeuwenhorst

${ }^{85}$ RAL AG, inv. no. 334-10 f 14v; 334-41 f 29v.

86 Van Kan, Sleutels tot de macht, 88-89.

87 Studer, 'India and the Great Divergence', 402. 
Abbey) in Holland, Utrecht and Maastricht in the eastern Low Countries, Bruges and Ghent in Flanders, Brussels and Louvain in Brabant, and the London region and Exeter in England. Figure 15 presents the results. For each location, a scatter plot and a logarithmic regression line display the correlations with the other eight locations related to distance. For greater clarity the graph is split into three panels.

The position of a regression line relative to the other regression lines indicates the overall degree of market integration between a given market and the other markets in the North Sea region. The regression line for Noordwijkerhout is highest, suggesting that by the early 15th century wheat markets in Holland-or at least in the central part of Holland-were very well connected to markets in the neighbouring regions. The slopes of the regression lines indicate the degree to which market integration depended on distance. The regression line for Noordwijkerhout is quite flat: this indicates that Holland markets were not only well integrated with foreign markets nearby, but also with those further away. In this regard, however, Holland is not unique: the markets in the southern Low Countries display similar flat slopes.

The slopes for London and Exeter and also for Utrecht are much steeper, suggesting a more rapid decline of market integration with increasing distance. For Utrecht this might perhaps be explained by higher transport costs: Utrecht was an inland town and did not have good access to waterways. However, in the case of London and Exeter, transport costs can do little to explain the difference from Holland. Both towns had easy access to the sea, yet this did not stimulate integration with distant markets to the same degree as in Holland. The English grain market was clearly relatively self-contained: as long as it could sustain its own population, there was no need to go further afield.

The position of Holland can be studied in more detail by looking at the development of wheat prices over time. Table 6 shows that even though for the period as a whole correlations are high, fluctuations in time were considerable. In the years between 1410 and 1420, and especially between 1430 and 1440, correlation coefficients were, generally speaking, higher than in the intermediate decade. Between 1420 and 1430 the link between the Leeuwenhorst prices and those in the towns of the southern Low Countries remained fairly strong, but the connections to Utrecht and Maastricht were much weaker than before, and the link with England was completely severed. 

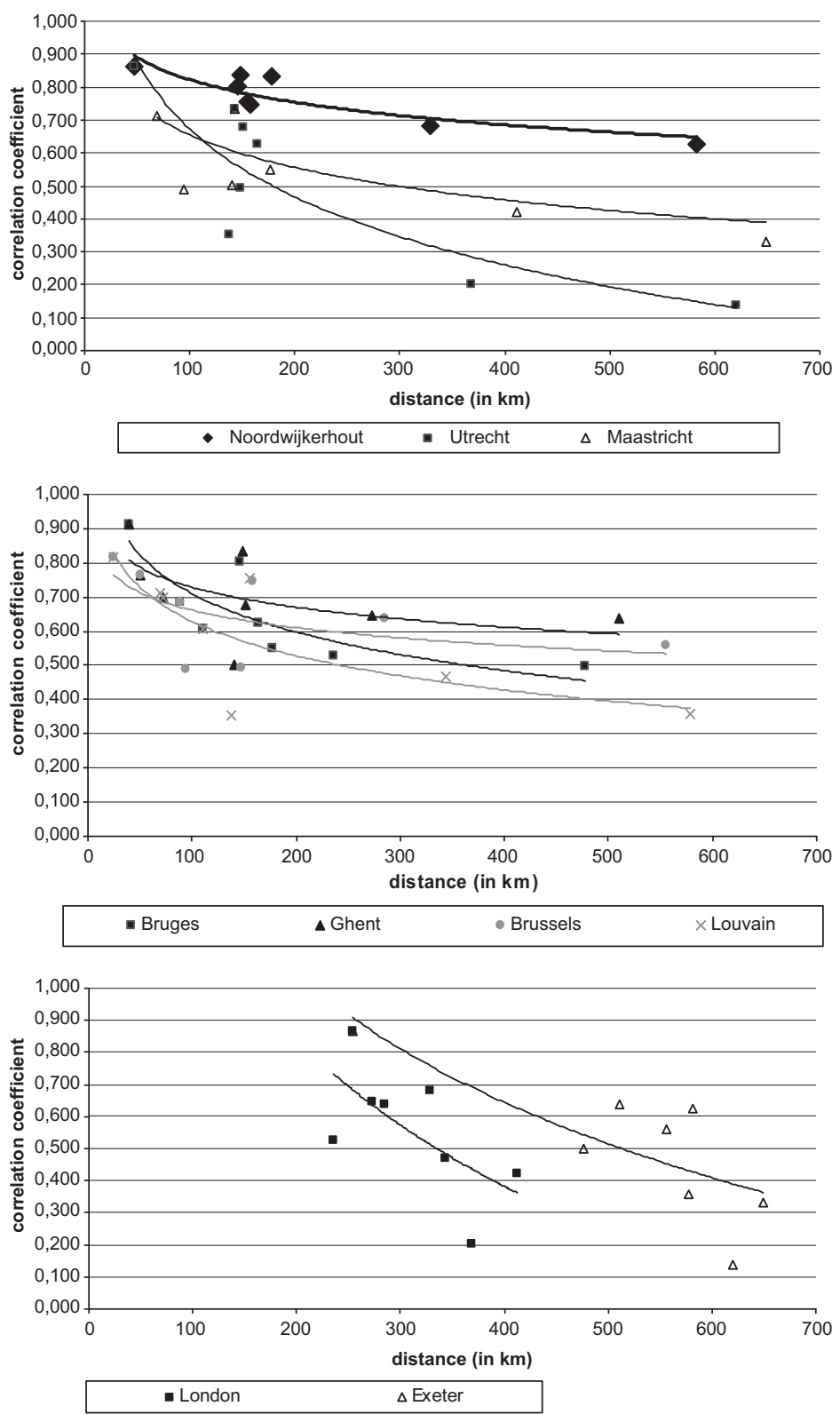

Figure 15 Correlation coefficient of logs of annual average wheat prices (in grams of silver per hectolitre) between nine locations in Holland and the eastern Low Countries, the southern Low Countries, and England, related to the distance between locations, $1410 / 11-1439 / 40$ Sources: see Appendix D 
Table 6 Correlation coefficient of logs of annual average wheat prices (in grams of silver per hectolitre) between Noordwijkerhout and seven other locations in the Low Countries and England per decade, 1410/11-1439/40

\begin{tabular}{lllll}
\hline $\begin{array}{l}\text { Noordwijkerhout } \\
\text { with: }\end{array}$ & $1410 / 11-1419 / 20$ & $1420 / 21-1429 / 30$ & $1430 / 31-1439 / 40$ & $\begin{array}{l}\text { Entire } \\
\text { period }\end{array}$ \\
\hline Utrecht & 0.599 & 0.472 & 0.985 & 0.862 \\
Maastricht & 0.955 & 0.558 & 0.885 & 0.831 \\
Bruges & 0.597 & 0.682 & 0.974 & 0.803 \\
Ghent & 0.830 & 0.899 & 0.902 & 0.835 \\
Brussels & 0.869 & 0.697 & 0.776 & 0.747 \\
Louvain & -0.516 & 0.759 & 0.831 & 0.756 \\
London region & 0.907 & -0.533 & 0.911 & 0.681 \\
Exeter & 0.831 & 0.153 & 0.807 & 0.626 \\
\hline
\end{tabular}

Sources: see Appendix D

General dearth in the years $1415 / 16$ and $1437 / 38$ probably explains the high coefficients for the two corresponding decades. To some extent, these figures may be flattered: these are two examples of years when widespread harvest failure due to adverse weather conditions over a wide region may have driven up prices everywhere, thus raising correlation coefficients regardless of the actual degree of market integration. However, we saw that in times of dearth prices also tended to move in concert for another reason, one that does reflect a real increase in integration: scarcity induced merchants to search for supplies much further afield than they would normally have done. Therefore, at least part of the fluctuations is probably real: Holland grain markets were not as well integrated with markets abroad during the 1420s as before and afterwards. ${ }^{88}$

Admittedly, Holland currency was far from stable in this decade, but it had also been highly unstable between 1410 and $1420 .{ }^{89}$ Moreover, the fall in the level of integration was not restricted to Holland alone: except for the links between Leeuwenhorst and the towns in the southern Low Countries in the 1420s, almost all connections across national borders were weak. The most likely explanation is simply the

${ }^{88}$ I can offer no explanation for the negative correlation with Louvain between 1410 and 1420, but it is likely the cause is to be found in local circumstances: for this decade, correlations for wheat prices between Louvain and all other towns except Brussels are weak or non-existent.

${ }^{89}$ Grolle, Muntslag, 145-147, 158, 179-180. 
absence of years of serious shortages, which maintained grain prices at modest levels and thus temporarily removed the stimulus to international trade.

The findings allow for a reconciliation of two apparently contradictory views on interregional market integration: on the one hand, Söderberg's statement that in the early 15th century an interregional grain market functioned in northwestern Europe; and, on the other hand, Unger's denial of the existence of such a market. It is clear that there were links-some of them very strong-between grain markets in northwestern Europe. However, the result was anything but a tightly-knit and stable entity. The data indicate a mix of bilateral links of different strength, reflecting stronger or weaker trade connections. Moreover, they suggest a pattern of very considerable upward and downward fluctuations in the level of integration, initiated at least in part by the occurrence or absence of years of dearth. ${ }^{90}$ In other words, an interregional market network did exist, but it was far from homogeneous and tended to contract when and where the need for longdistance grain trade was obviated by abundant harvests.

In this heterogeneous and unstable network, Holland was the region with the strongest and most durable links to other markets in the North Sea region. Clearly, the explanation for this situation hinges on Holland's dependence on imports. Nevertheless, there is good reason to believe market structures-by facilitating these importsalso contributed. If we follow the route that grain imports took, we encounter several elements of the institutional framework discussed in earlier chapters that may have played a part. The first is the rise of sea-fishing and village fish markets. In her study on commercial relations between Holland and England, Nelly Kerling argues that in the late 14th and early 15th century the grain trade from Great Yarmouth and King's Lynn to Holland was partly conducted by London fishmongers who visited the coastal villages of Holland, offering corn in exchange for fish. ${ }^{91}$ Even if volumes were modest, as they probably were, this does demonstrate how the near absence of restraints on rural commerce in Holland may have helped to facilitate grain imports.

\footnotetext{
${ }^{90}$ James Galloway arrives at a similar conclusion for England in the 14th century (Galloway, 'One Market or Many?', 37).

${ }^{91}$ Kerling, Commercial Relations, 108.
} 
The second element is the fact that, despite Dordrecht's official monopoly on the grain trade in the delta of the Rhine and the Meuse, other towns-by making use of every legal and geographical loophole, but also by lobbying and making alliances-managed to develop profitable trade activities themselves. One of these towns was Brielle. Merchants from Brielle are also found, and in greater numbers than Dordrecht merchants, exporting grain (and cloth) from King's Lynn in that city's customs account over the year 1392-1393..$^{22}$ Another new trade centre was Delft. By the middle of the 15th century, and quite possibly earlier than this, Delft had developed beyond a market centre for wheat grown in the region; it had become an important market for 'western' grain as well. ${ }^{93}$ In Flanders, on the other hand, Ghent continued to dominate the transit grain trade until the early 16th century, much to its own benefit but at the expense of other towns, who were unable to develop their own grain trading activities. ${ }^{94}$

Finally there is the near absence of restrictions on, or taxation of, international trade. In this respect Holland compares favourably to England. Medieval Holland did not know a licensing system for international trade; notably, whereas in the early 16th century, export licenses were successfully re-introduced in England, attempts by the Habsburg authorities to do so in Holland for the growing transit grain trade ran into such fierce opposition that the idea had to be abandoned. ${ }^{95}$ Apart from the river tolls, which were levied at low rates and from which most Holland merchants were exempted anyway, grain imports were not taxed. In 14th-century England, on the other hand, the national customs system expanded to cover a larger range of products, while rates moved upward. Poundage for instance, the imposition on the export of 'general merchandise' (including grain), increased from $1.25 \%$ in the early 14 th century to $5 \%$ around $1400 .{ }^{96}$

There can be no doubt that grain imports would have taken place in Holland no matter how the institutional framework was shaped. They also took place in Flanders, under very different conditions, and in England too if the need was there. However, whether they would have

92 Gras, Early English Customs System, 526-553.

${ }_{93}$ Van Tielhof, Hollandse graanhandel, 16-18.

${ }_{94}$ Bigwood, 'Gand et la circulation', esp. 401-410, 453-456, 459-460.

${ }_{95}$ Gras, Evolution of the English Corn Market, 225-226 (England); Meilink, 'Rapporten en betoogen nopens het congégeld op granen, 1530-1541', 1-21, and Van Tielhof, Hollandse graanhandel, 132-138 (Holland).

${ }_{96}$ Gras, Early English Customs System, 80-82, 121. 
developed as strongly as they did, and with the same prolonged success, is another matter.

\subsection{Conclusions}

This chapter tests one of the central theses of this book-the idea that in late medieval Holland a framework of market institutions developed that raised market performance-by assessing the integration of markets for wheat in the late 14th and early 15th centuries. The results are not as straightforward as the hypothesis suggests.

Whereas theory predicts that, in a well-integrated market, price volatility is relatively low, in Holland prices fluctuated as much as in the neighbouring regions. In fact, during the food crisis of the late 1430s, wheat prices mounted to higher levels than elsewhere. Moreover, although wheat prices within the county-as far as the scarce data allow for conclusions-moved in close concert, in this Holland was by no means unique: the grain markets of England and the southern Low Countries were also well integrated. Apparently, the presence of a favourable institutional framework did not give Holland an advantage. Certainly, grain market institutions in Holland, England and the southern Low Countries bore a closer resemblance than the institutional frameworks governing exchange in many other commodities: authorities everywhere tried to prevent grain shortages, or at least dampen their consequences, through regulation. In the face of the needs of grain provisioning, differences in the institutions governing the internal grain trade disappeared to some extent. Nevertheless, even when these differences continued to exist, they apparently did not affect market performance that much.

Only when Holland wheat price series are compared with those in neighbouring regions do differences in the level of market integration appear. In the early 15th century, an interregional grain market in northwestern Europe existed, but it was far from homogeneous or stable, contracting when and where grain was abundant. Here Holland does stand out: its multilateral interregional links were stronger and more consistent than England's or those of the southern Low Countries. That this did not lead to a reduction of price volatility can be explained by the vulnerability that came with a dependence on imports: in times of dearth, export restrictions in the producing regions could cause acute problems in Holland. 
Good access to water transport can, at most, provide a very partial explanation for Holland's well-established interregional connections: these connections largely depended on sea transport, to which several of the other towns mentioned in this chapter also had good access. Holland's dependence on grain imports, on the other hand, is an important explanatory factor. The driving force behind Holland's interregional grain trade was the demand for bread grains, and no doubt regulations and trading practices were adapted to suit this purpose. Under the influence of pre-existing traditions, the direction this process of adaptation took-moving towards easily accessible markets and few restraints on trade-was, however, different from what happened in England or, more to the point perhaps, in the southern Low Countries, a region where large quantities of grain were also imported but under very different conditions. If market structures had been less favourable, it is doubtful whether Holland would have been able to build up the same robust and wide-flung interregional trade network. 